Fort Hays State University

FHSU Scholars Repository

Master's Theses

Graduate School

Summer 1940

\title{
The Effect of Clipping and Weed Competition Upon The Spread of Pasture Grass Seedlings
}

Cecil L. Hase

Fort Hays Kansas State College

Follow this and additional works at: https://scholars.fhsu.edu/theses

Part of the Biology Commons

\section{Recommended Citation}

Hase, Cecil L., "The Effect of Clipping and Weed Competition Upon The Spread of Pasture Grass

Seedlings" (1940). Master's Theses. 323.

DOI: $10.58809 / \mathrm{JOYH} 3706$

Available at: https://scholars.fhsu.edu/theses/323

This Thesis is brought to you for free and open access by the Graduate School at FHSU Scholars Repository. It has been accepted for inclusion in Master's Theses by an authorized administrator of FHSU Scholars Repository. For more information, please contact ScholarsRepository@fhsu.edu. 


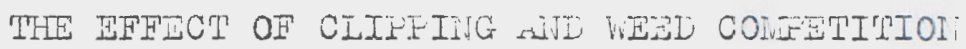

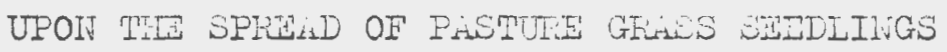

being

A thesis presented to the Graduate Faculty of the Fort Lays Kansas State College in partial fulfillment of the requirements for the Degree of lister of Science

by

Cecil I. Base, A. B.

Fort Hays Kansas State College

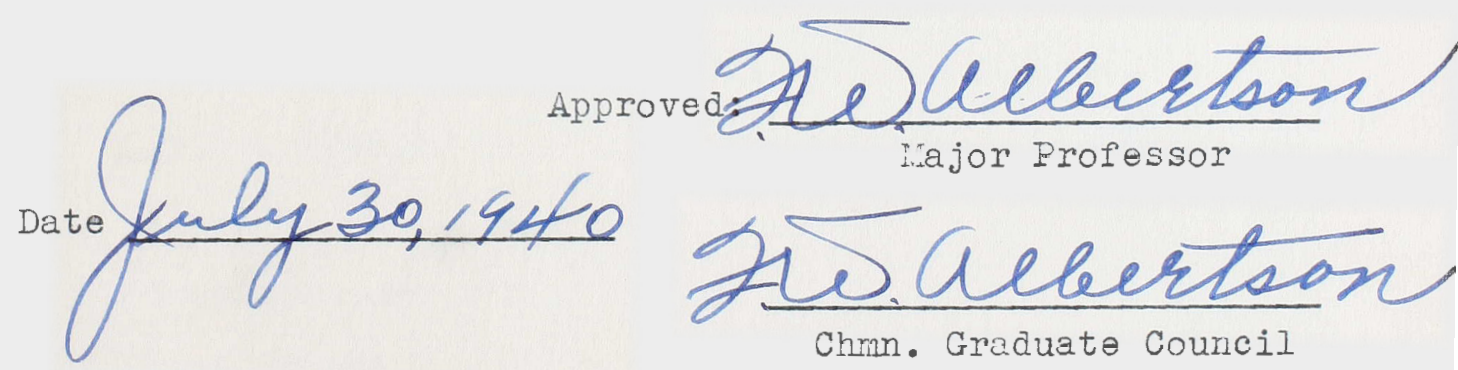


A C K N O WL $\mathrm{E} D$ G

The autior of this paper wishes to acknowledge all sources of information used in its preparation. He is especially indebted to Dr. F. . . Albertson, who supervised the problem, to Irr. D. A. Fiegel, for his assistance in photograming the material, and to Mr. John ".ebb, viho inked and lettered tis dravings. 


$$
\text { C O NTS I T S }
$$

$\mathrm{Pa}$ Te

INTRODUCTION . . . . . . . . . . . I

FUITD ETUDSES. . . . . . . . . 2

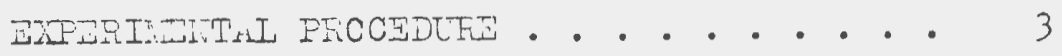

Selecting the Seed......... 3

Preparation of the seed Bed . . . . . 4

Planting the Seed . . . . . . . 4

Arrangement of Ixperimental Plots . • 5

Treatment of Ixperimental plots . . . 5

E巴SULTS. . . . . . . . . . . . 9

Buffalo Grass

(ground cover and root system) . . . 9

Blue Grama Grass

(ground cover, yield, root systen, tillers)...... 15

Side-0ats Grania Grass

(ground cover, yield, root system, tiliers)......

DISCUSSION . . . . . . . . . . 24

Tiller Growth . . . . . . . . 27

Yield............. . . 28

Ground Cover. . . . . . . . . . 28

Root Growth . . . . . . . . 29

APPLICATIOHT. . . . . . . . . . . 30

SUMHY. . . . . . . . . . . . 31

BIBLIOGRAPHY . . . . . . . . . . 32 
FIGURE

1 The general arrangement of the experimental

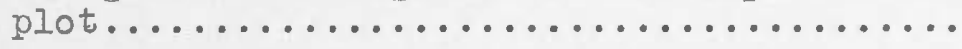

2 A general view of the experimental plot....

3 A view showing the height of clipping of buffalo grass and blue grama grass........

4 Trench in which the roots of the different

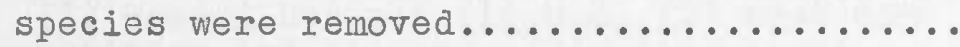

5 Typical buffalo grass quadrats. Quadrat 1-3, weeded but not clipped, $2-3$ clipped plus weed competition, and $3-3$ weeded and

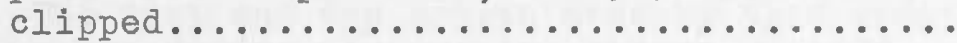

6 Typical quadrats of buffalo grass showing the effects of the various types of treat-

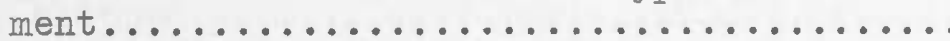

7 The root systems of the various species

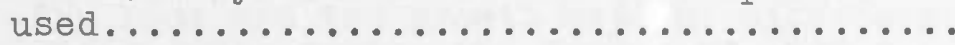

8 Typical blue grama grass quadrats selected to show the effects of the various types of

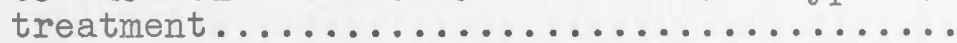

9 Typical blue grama quadrats. $(A-1-3)$ weeded and not clipped, $(A-2-3)$ not weeded but clipped, $(\mathrm{A}-3-3)$ weeded and clipped........

10 Typical side-oats grama grass quadrats subjected to the various types of treatment......... 23

11 Typical side-oats grama quadrats, (B-1-3) weeded but not clipped, (B-2-3) not weeded but clipped, and $(\mathrm{B}-3-3)$ weeded and clipped 


\section{I T O F T A B I E S}

TABLE

PAGE

I Iist of ruderals growing in the clipped quadrats with weed competition...........

II Basal cover made by buffalo grass under the various types of treatment during 1939. (1) Weeded but not clipped, (2) weed competition and clipped, (3) clipped and

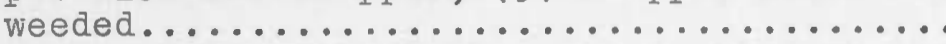

III The root and top growth made by blue grama grass during the growing season of 1939. (A-1) Weeded and not clipped, $(\mathrm{A}-2)$ not weeded but clipped, and $(\bar{A}-3)$ weeded and

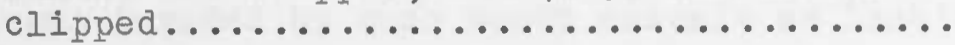

IV The root and top growth made by side-oats grama grass during the summer of 1939. (B-I) Weeded but not clipped, (B-2) not weeded but clipped, and $(B-3)$ weeded and

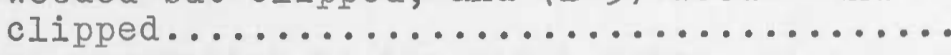


The drought of the last seven years vith its disastrous dust storms has damared vast areas of the native prairie as well as much of the cultivated land. Deficient rainfall has caused crop failures over large areas, leaving the fields without a protective covering. Due to these conditions, wind erosion started the ary, loose soil to arifting. Larje amounts of the soil settled on tlie grassland anc destroyed much of the native plant cover (10). Where the native vegetation was veakened or destroyed, the soil was invaded by such weedy annuals as lamb's quarter (Chenopodiur sp.), Russian thistle (Salsola pestifer), pig weed (Amaranthus sp.), and sunflover (Felianthus annuus). The severe competition of these ruderals further vealened the native veretation to the point vinere, in many cases, it was completely destroyed.

These conditions have brought about an increased activity in the field of range research. Until recently there has been relatively little research vork done on the revezetation of cultivated land. The greater part of the experimental work, prior to the drought, was carried out with the intention of using domestic forage plants to revegetate the depleted ranges $(8)$. 
The present needs in range research are nore experimental data on native fowaje plants and the methods of hanaling them on revegetation areas. It is nore practical to obtain tilis information on sinall experimental plots tian on large revegetation areas vilere improper linethods might prove too costly.

To provide a part of this needed infornation, an experiment was set up at Hays, Kansas, in the spring of 1939 to deterinine the effect of clipping and weed competition on the spread of pasture grass seedlines.

$$
\text { R I I T } \mathrm{I} D \text { D T U D I I S }
$$

iost of the experinertal wor relative to clippinc has been done on tre effect of clipping und fertilizin: upo: the yield and composition of the forage. Ieuiel, caro, and Coleman (3) and kobinson, rierre, and seliernan (5) woried on the effect of clipping and nitrate fertilizins on the sro:th behavior anò composition of pasture Erasses. hichardison, Trumble, and Shapter in isustralia (4) studied the influence of the crovtin stage and tie frequency of cutting on tile vielà ana composition of rinalaris tuberosa. They found tilat frequent cutting greatly reduced the yiela of the tops and tine extent of the root system. Two or three cuttines a year, Lowever, had a tendency to increase the yield. 
Nearly all the work on revegetation, until very recently, was done in the west and soutiwest with the use of inported and cultivated snecies (j). These studjes were not very recent and for the inost rart did not prove successful because of the inability of tilese introduced plants to become adjusted to the arid clinate of those regions.

To tile autior's knowledce, no detailed study ias been rade of the effects of clipyins and weed conpetition on the increase of basal cover, which is so inportant on reveretation areas. Lobertson (7) studied the effects of clinping on the yield of six rance anç pasture erasses, but his work was conducted entirely in the greenilouse where the environment is vastly different frow that of the cultivated iield.

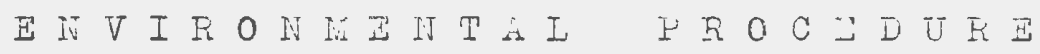
SELECTIIV TEU SEDD

The seed selected was secured near liavs, Iiansas, and had been collected not earlier than 1938. The buffalo srass (Buchloe dactiloides) had a viability of 2 to 2.5 - er cent. The burs were planted vithout any atteinot to separate the caryopses because of the low ermination rate.

rhe blue grama srass (Bouteloua gracilis) had a germination percentage of about 2 per cent. The spikes of tile blue grana were separated into separate florets because of the 
size of the spikes.

The side-oats grama grass (Bouteloua curtinendula) seed had a cermination of 3 to 4 per cent. rine spikes of this grass were not broken up before plantine, except where they had broken apart in hanàling.

\section{PREPARATIOIN OF THE STTD BED}

The experinental tract was located on good creek bottom soil which was well drained and equipped with an overhead irrigating system. Small dykes were put in where needed to prevent heavy rains fron vashins out the seedlinss.

In preparine the seed bec, the weeds were removed with a hoe and only the surface of the soil was disturbed. The crouna was thei raked and wet down ith the overiead irrigating systen. wfter desirable noisture coüitions were obtained, the rround was leveled by pulling a heavy plankover it.

\section{PLIITIIG THE SED}

The seed was planted oll liay 30 in meter-sized qusdrats. The seed was scattered by wand and then covered by sifting soil over it to the depth of about one-fourtin inch.

The plot was wet down again after the planting was conpleted and kept moist thereafter until tıe seedlings appeareä. 
Water deficiency was never allowed to becone a liniting factor timroughout this experiment.

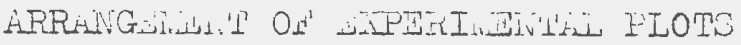

There were twelve quadrats for each species, arranged in three series of four quadrats each. The plots vere spaced eighteen inches apart and oriented along a rorth and south line (Figs. 1 and 2). 'the quadrate in each series were numberea consecutively from tıe nortin side of the experimental area. 'l'le tiree series were nubered in orcier from left to right for each species. 'line series of buffalo crass were assigned 1,2 , and 3 ; those of blue grana srass, $A-1, A-2$, and $A-3$; and tiose of side-oats $\approx r a i r a, B-1, B-2$, and $B-3$.

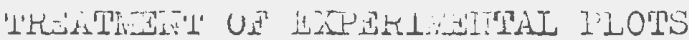

Series l of eaci spocies vas kent free of veeds but ras not cliyed until t:e end or the roning season. Series 2 did not have the veeds removed but both weeds and urass were clipped to the sane height at two to three weei intervals. In cljping, tie rass vas cut at a nei int of one inch in order to simulate overgrazirs as nearly as possible (Fic. 3 ). tqual nurbers of plants were staked and nubered for tiller counts in the blue grama and side-oats srana quadrats. 


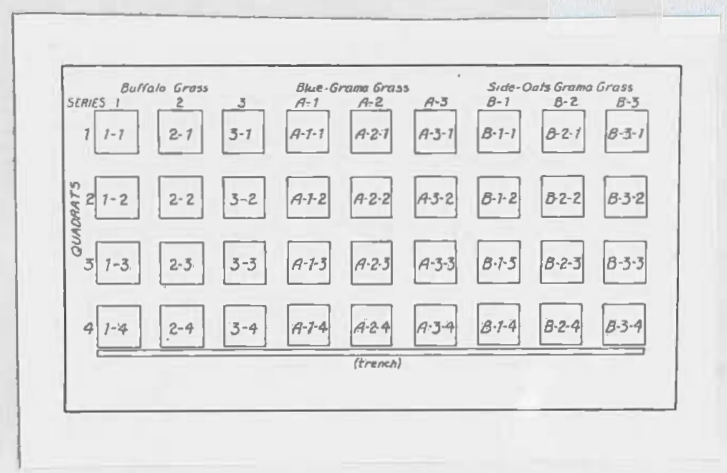

Fig. 1. The general arrangement of the experimental plot. 


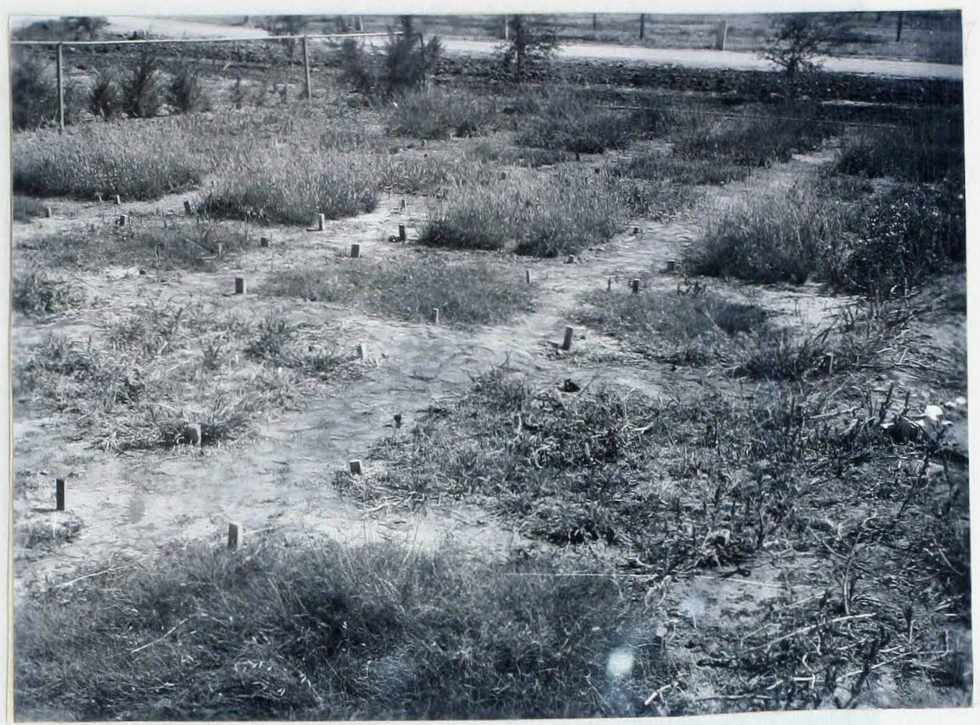

Fig. 2. A general view of the experimental plot. 

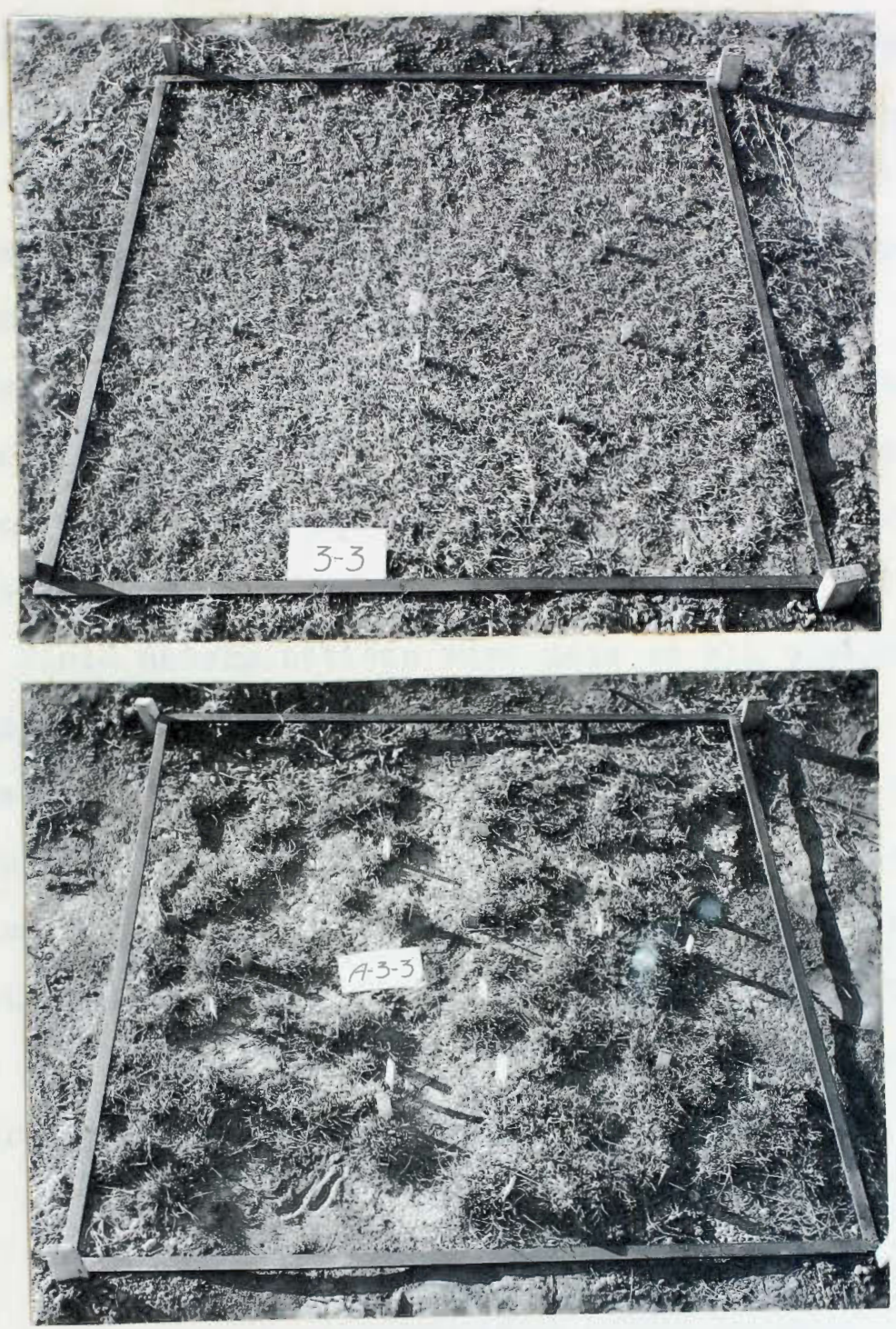

Fig. 3. A view showing the height of clipping of buffalo grass (above) and blue grama grass (below). The small stakes shown are about two inches high. 
The tillers on these plants were counted four tines during the season. It was impossible to keep the saine type of record on the buffalo grass because of its stoloniferous habit of sowth. The solid mat wich this grass fomed made it impossible to identify individual nlants.

Lantorran records were made of all the quadrats, with the exception of quadrat nuber 4 in eaci series, wich vas used for root study. Fhotosraphic records viere made of quadrat nuinber 3 in each series, both before anc after clipping. Yieló determinations were made on all excent the buffalo crass series. The deptin and spread of the root systems were àetermineã and photographed.

The root systems were studied by äizeing a trench lbisect) seven feet deep along the end of the plot (Fic. 1). The soil was removed from the roots by working it loose with an ice pick and carefully washing it away with water under pressure (Fig. 4 ).

$$
\text { R E S I T S }
$$

The three grasses used responded to the various types of treatinent as follows.

\section{BUFF'}

Buffalo grass was the last to Eeminate of the three grasses used in this study; the first seedlings apjeared 


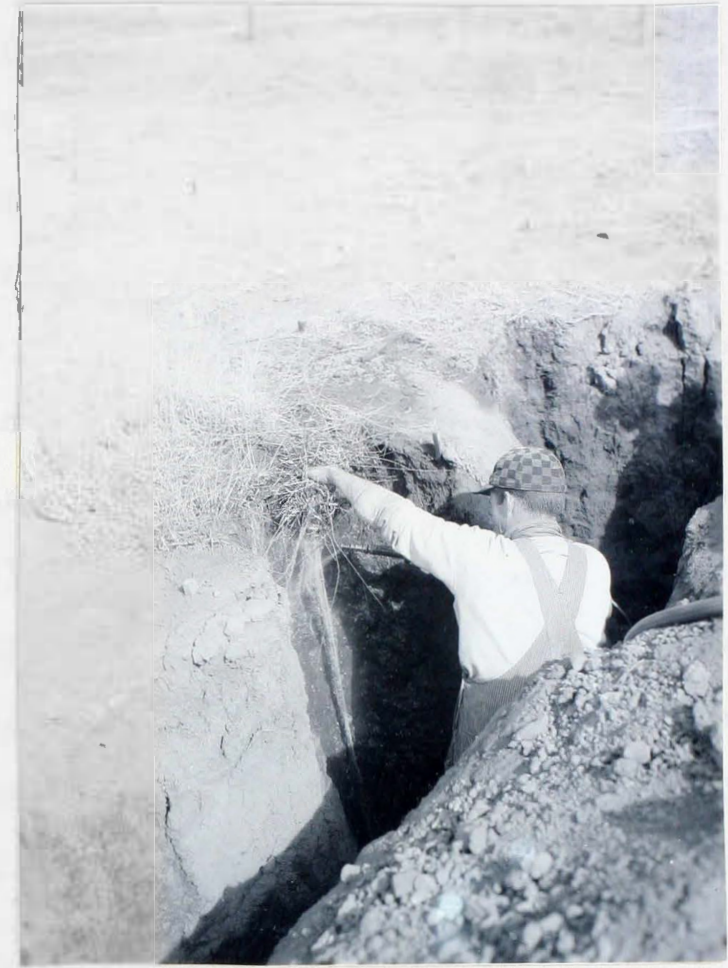

Fig. 4. Trench in which the roots of the different species were removed. 
on June 12. They were all vigorous plants and were well distributea over the ¿uadrats.

The rass in series 1 procuced an avera :e basal cover of 75 per cent at the close of the season. The vigorously Erowing leaf blades often ielc the stolons so hish above the soil that rootine at the nodes was impossible (3).

The excessive weec competition in ceries 2 ereatly affected the mroth of buffalo crass. The basal cover remained near zero during the entire season. There was no stolon srowth until sucust, and only a fev were longer than one inch. Tach tije the quadrat vas clipped, a new crop of fast growing annual weeds (Table I) would spring up and soon vas tali enough to shace the buffalo grass. The average basal cover at tne end of tise season was only 0.33 per cent (Fig. 5).

The cover in series 3 , which was weeded and clipped at regular intervals throu hout the season, avera ed 66. p per cent. The clippin permitted the stolons to mrow on the surface of the soil where they took root quichly and greatly increased the cover. In these quadrats it was necessary to cut off the stolons at tine edce of the quadrat to keep tilem from spreadin across the alleys to the otiner quadrats (Fis. 6).

The heaviest basal cover did not indicate the most extensive root systens. The root system of Series 3, wili 
TABIT I. List of ruderals rowine in the clipfed quadrats with weed coinetition.

\begin{tabular}{|c|c|}
\hline Technical Iiarne & Corrion liame \\
\hline Amarantius retroflexus & pig weed \\
\hline Carex raviòa & sedre \\
\hline Cencinus rauciflorus & sandbur \\
\hline Chamaesyce slyotosperna & nat spurze \\
\hline Chenoiodiu album & lamb's quarter \\
\hline Cilonis venticillata & vilirill grass \\
\hline Disitaria sanłuinalis & crabsrass \\
\hline Tranrostis cilianensis & love grass \\
\hline Teliaritus amuus & sunflover \\
\hline Lactuca ludoviciana & western lettuce \\
\hline Panicun carillare & witerinass \\
\hline Salsola pestifer & Dussian tilistle \\
\hline Setaria lutescens & ye-lor foxtail \\
\hline Setaria viridis & green foxtail \\
\hline Sporobolus cryptandrus & sand coropseed \\
\hline Tribulus terrestris & Texas sandbur \\
\hline
\end{tabular}




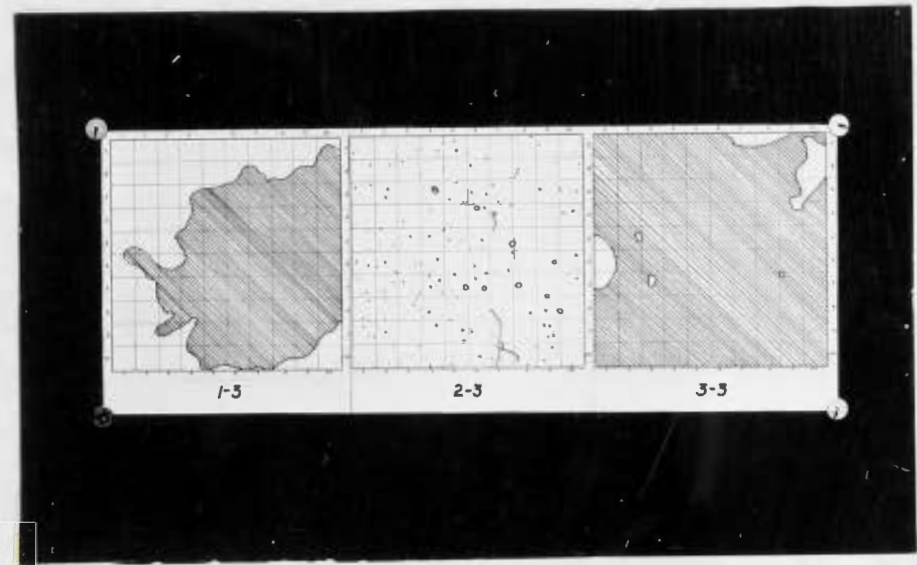

Fig. 5. Typical buffalo grass quadrats. Quadrat I-3, weeded but not clipped, 2-3 clipped plus weed competition, and $3-3$ weeded and clipped. 

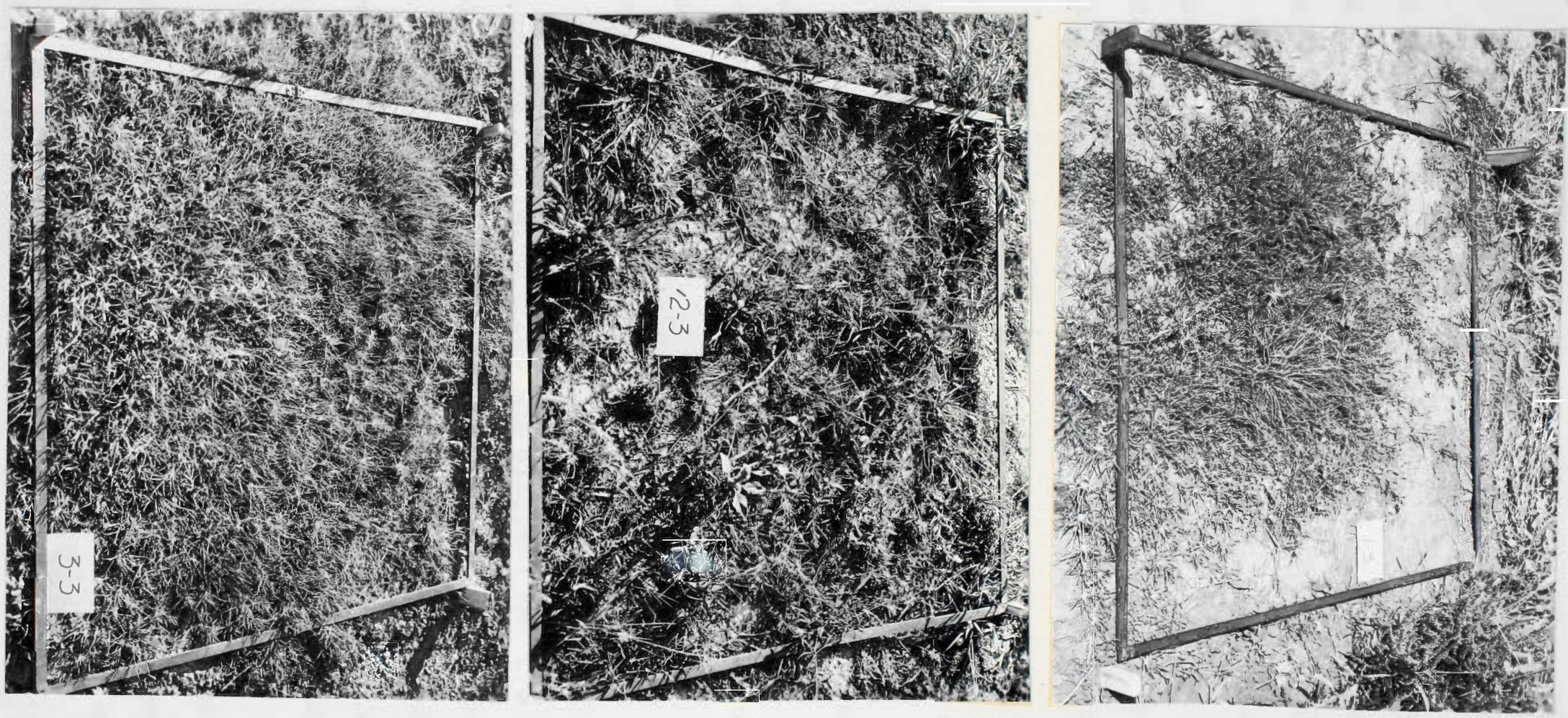

Fig. 6. Typical quadrats of buffalo grass showing the effects of the various types of treatment. In 1-3 (weeded but not clipped) the leaves are long and heavy, holding the stolons above the soil where they cannot take root. In $2-3$ (not weeded but clipped) the cover is very sparse and mostly of weeds. In $3-3$ (weeded and clipped) the cover is heavy and the stolons grow close to soil where they take root readily and have spread outside the quadrat. 
had yroduced the heaviost eround cover, had a depti of four anù one-half feet and a spread of fourteen inches (Table II). The rcot sjstem of Jeries I was tie heaviest, havine a depth of five reet anci a sprea of twenty inches. The least extensive root systein was produced in Veries 2. This series, under seed competition and clippinc, produced a root systeín only thirty inches deep witi a spread of four inches (Fi. 7).

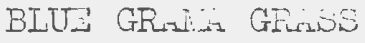

Twenty-five blue erana crass jlants per cuadrat were stalrod for jield deter inations. Tilese yislcs were conputed or tile basis o $\vec{i}$ rans for twenty-five plants per quadrat. Tiese ulants iere staked in o cier to have the sane numer of representative iants for each area.

The total seasonal yiela for tie trenty-ive plants in Jeries A-l (weeded but not clined) vas $17 \overrightarrow{0}$ grain of foraje per quadrat (Table III). The sane nuiber of plunts in Series $4-2$ (not weecied but clipped) produced only 27.8 grans aurings the same len th of time. rhe twenty-five plants in jeries 3 (weeded and clijped) yielded 126.4 srans durine the season.

The last clipping was delayed to allow for seed production under all types. leads vere vroduced under each treatment, but no caryopses were developed in any of the 
TABLF II. Basal cover made by buffalo mrass under the various types of treatment during 1939.

(1) Veeded but not clipped, ( 2 ) weed coupetition and clipped, and (3) clipped and veeded.

\begin{tabular}{|l|c|c|c|}
\hline series & 1 & 2 & 3 \\
\hline $\begin{array}{c}\text { Average } \\
\text { basal } \\
\text { cover }\end{array}$ & $75.65 \%$ & $0.33 \%$ & $86.87 \%$ \\
\hline
\end{tabular}



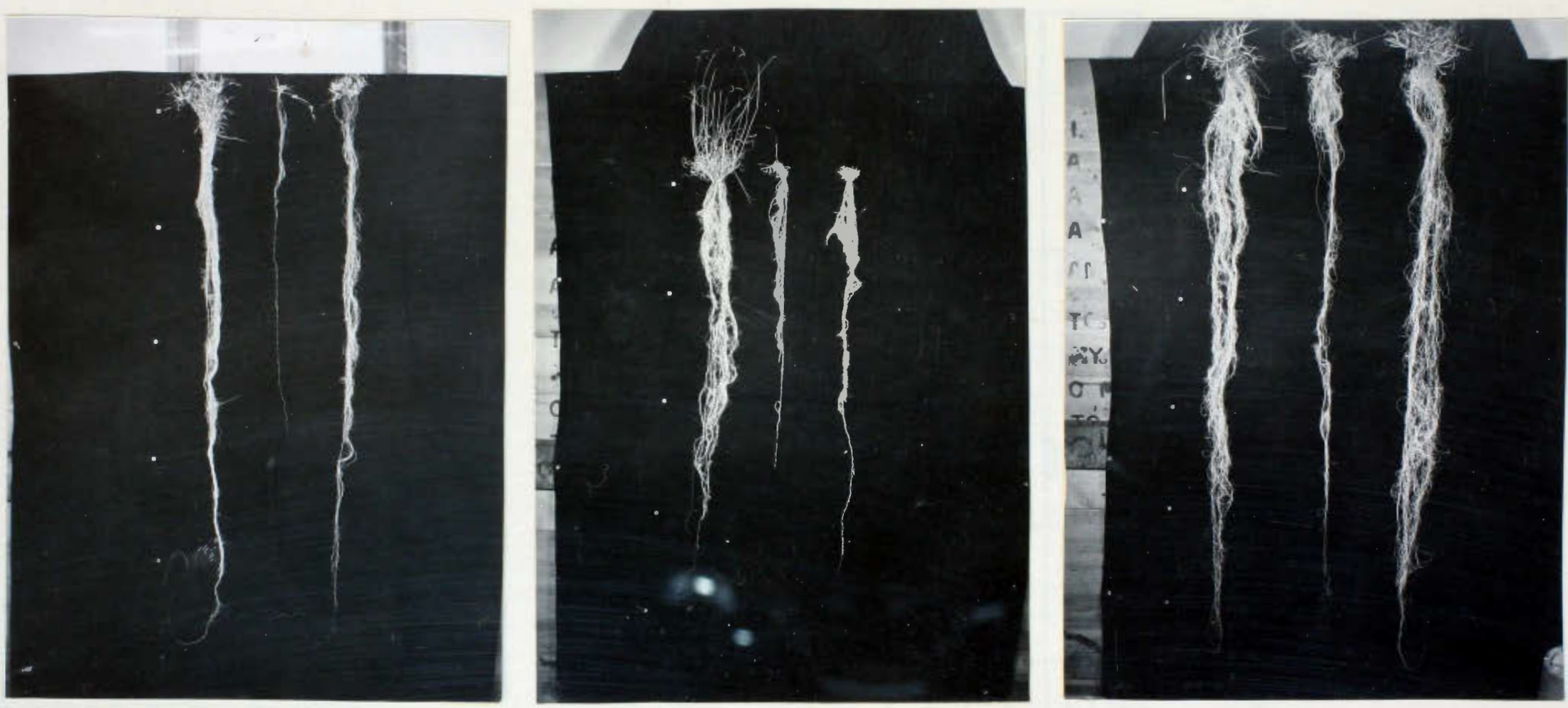

Fig. 7. The root systems of the various species used. From left to right are: buffalo grass, blue grama, and side-oats grama. The various types of treatment represented in each photograph are, beginning at the left: unclipped, clipped plus weed competition, and clipped. Bach dot represents 12 inches. 
TiBLi III. The root and top Grovti acie by blue Erana grass during the growing season of 1939. (A-1) Weeded and not clipped, $(+2-2)$ not weeded but clipped, and $(i 1-3)$ weeried and clipued.

\begin{tabular}{|c|c|c|c|c|c|c|}
\hline & \multicolumn{2}{|c|}{ Tillers } & \multirow{2}{*}{$\begin{array}{c}\text { Avera:e } \\
\text { yield } \\
\text { Lens.L }\end{array}$} & \multirow{2}{*}{$\begin{array}{l}\text { fverafe } \\
\text { basal } \\
\text { cover }\end{array}$} & \multicolumn{2}{|c|}{ root systeri } \\
\hline & roduced & $\begin{array}{l}\text { funber } \\
\text { survived }\end{array}$ & & & Len!tin & $\overline{s p r} \sim \bar{a}$ \\
\hline$\dot{x}-1$ & 60.3 & 08.3 & 176 & $13 ; 0$ & $4^{\prime} 2^{\prime \prime}$ & 201 \\
\hline$\dot{\mu}-2$ & 30.5 & 10.6 & 27.8 & $6 ; 0$ & $2 \cdot 6 "$ & $6^{\prime \prime}$ \\
\hline $1-3$ & 102.5 & 64.6 & 128.4 & 11,0 & $3 \cdot 6 "$ & $12^{2 t}$ \\
\hline
\end{tabular}


spikelets. The first heads were found on the weeded and unclipped quadrats on July 21. They first appeared on the weeded and clipped quadrats August 10, and five days later on the clipped but not weeded series.

The total number of tillers produced per plant was determined at the end of the season. The living tillers were separated from the dead ones to determine the effect of clipping upon tiller growth.

The grass plants of Series 1 produced an average of 68 tillers per plant, all of which were alive at the end of the season. Those of Series 2 produced an average of 30 tillers per plant but an average of only 19 of them remained alive at the end of the season. The average number of tillers in Series 3 was 102 per plant, 64 of which survived the season.

The weeded and unclipped series of blue grama had an average basal cover of 13 per cent at the close of the season. This was only slightly greater than that of Series A-3, which averaged 11 per cent. A combination of weed competition and clipping had a retarding effect on the blue grama in Series 2. The average cover here was only 6.4 per cent at the close of the season (Figs. 8 and 9 ).

The response of the root systems in the various quadrats to the different types of treatment was similar to that of buffalo grass. The roots of the weeded and unclipped 

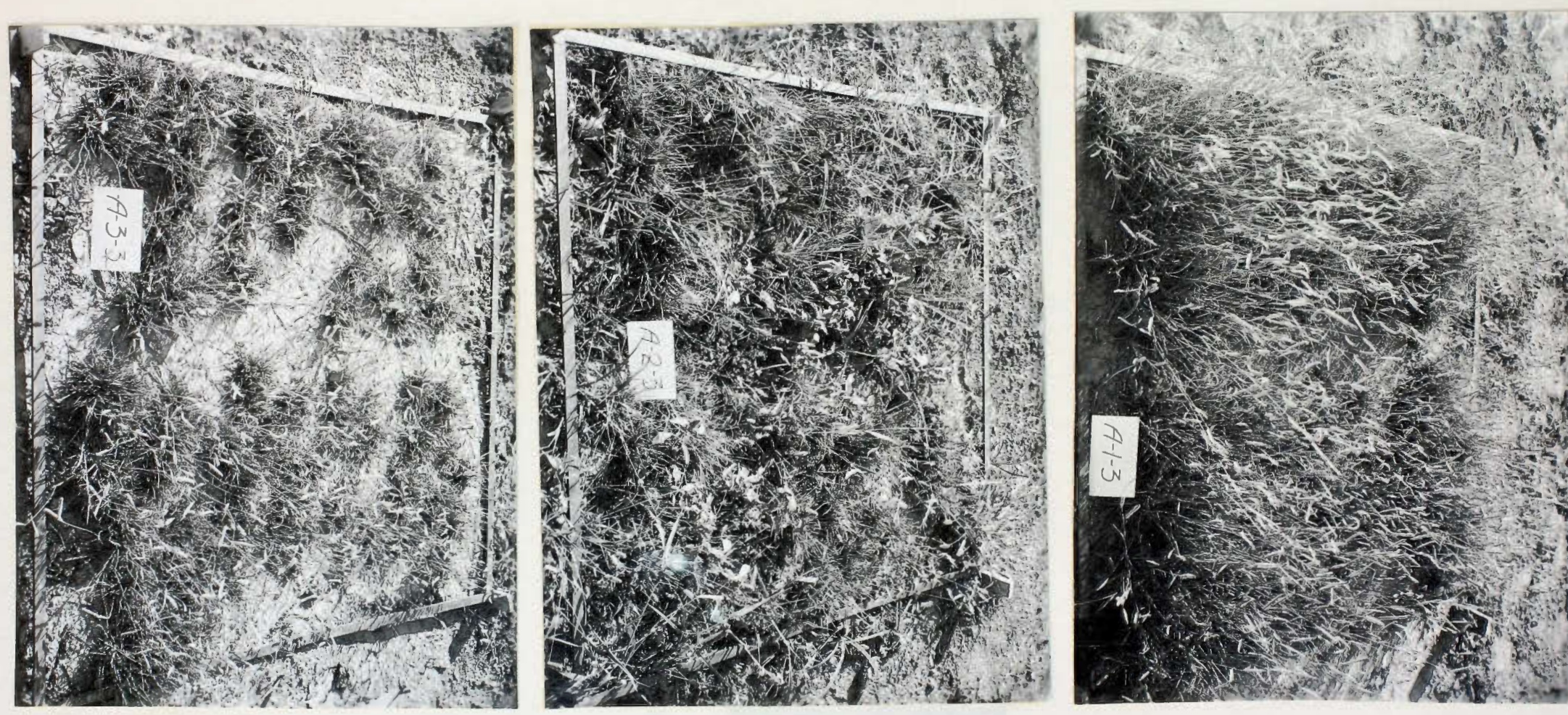

Fig. 8. Typical blue grama grass quadrats selected to show the effects of the various types of treatment. In $\mathrm{A}-1-3$ (weeded but not clipped) the forage is heavy, dense, and about eight inches high. The flower stalks are about fourteen inches high. In $\mathrm{A}-2-3$ (not weeded but clipped) the cover is sparse, short, and full of weeds. In $\mathrm{A}-3-3$ (weeded and clipped) the leaves and flower stalks are much shorter than those in $\mathrm{A}-\mathrm{I}-3$. 


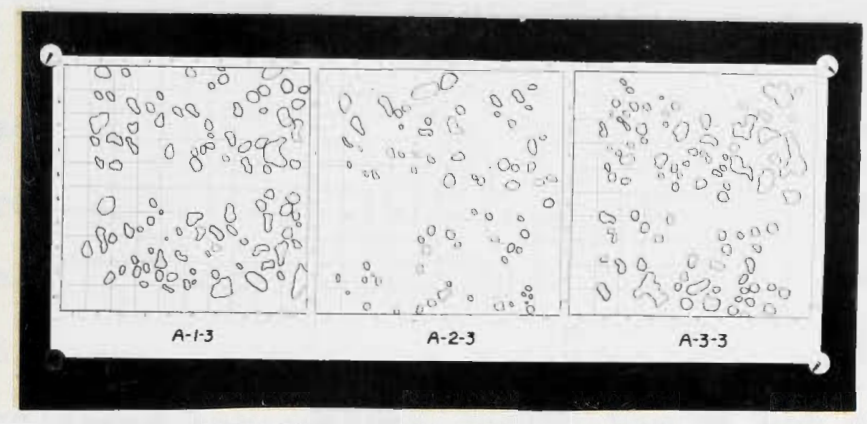

Fig. 9. Typical blue grama quadrats. (A-I-3) weeded and not clipped, $(A-2-3)$ not weeded but clipped, $(\mathrm{A}-3-3)$ weeded and clipped. 
series penetrated the soil to a certi of ifty inches. lhe roots in the weeded and clinpad series exterided to a dertin of forty-two inches. Veed corpetition and cliring greaty reduced tine root system of the series. Lts roots rere only thixty inches lons and tine number of roots per plant was mucil less than tilat of the otier two series ( $i \xi \cdot 7$ ).

\section{SIDE-OATS GLATH GRW SOS}

Representative plants were staked in the side-oats grana quadrats, similar to tiose in the blue grana series, but the yield was vased upon thirty plants per quadrat.

The tirirty plants in tire vieeded but uncliplea series averaged 159 srams per quadrat durins the season of 1939 . The clippea but not veedea series produceu about one-half as much, 82 grams, for the same season. The veeded and clipped series produced 111 grams curing the saie length of time.

Spikes vere produced in tie side-oats srama when the last clippink vas delayea (Fis. 10) but, as in tile forner species, no caryopses vere developed.

The total nuinber of tillers was determined at tire end of the season and the livin tillers were separated fron tire dead ones. The rreatest number of tillers, 143, vas produced in the weeded but unclipped series. All of these rere alive at tise end of the season. Series $B-2$ produced an average of 

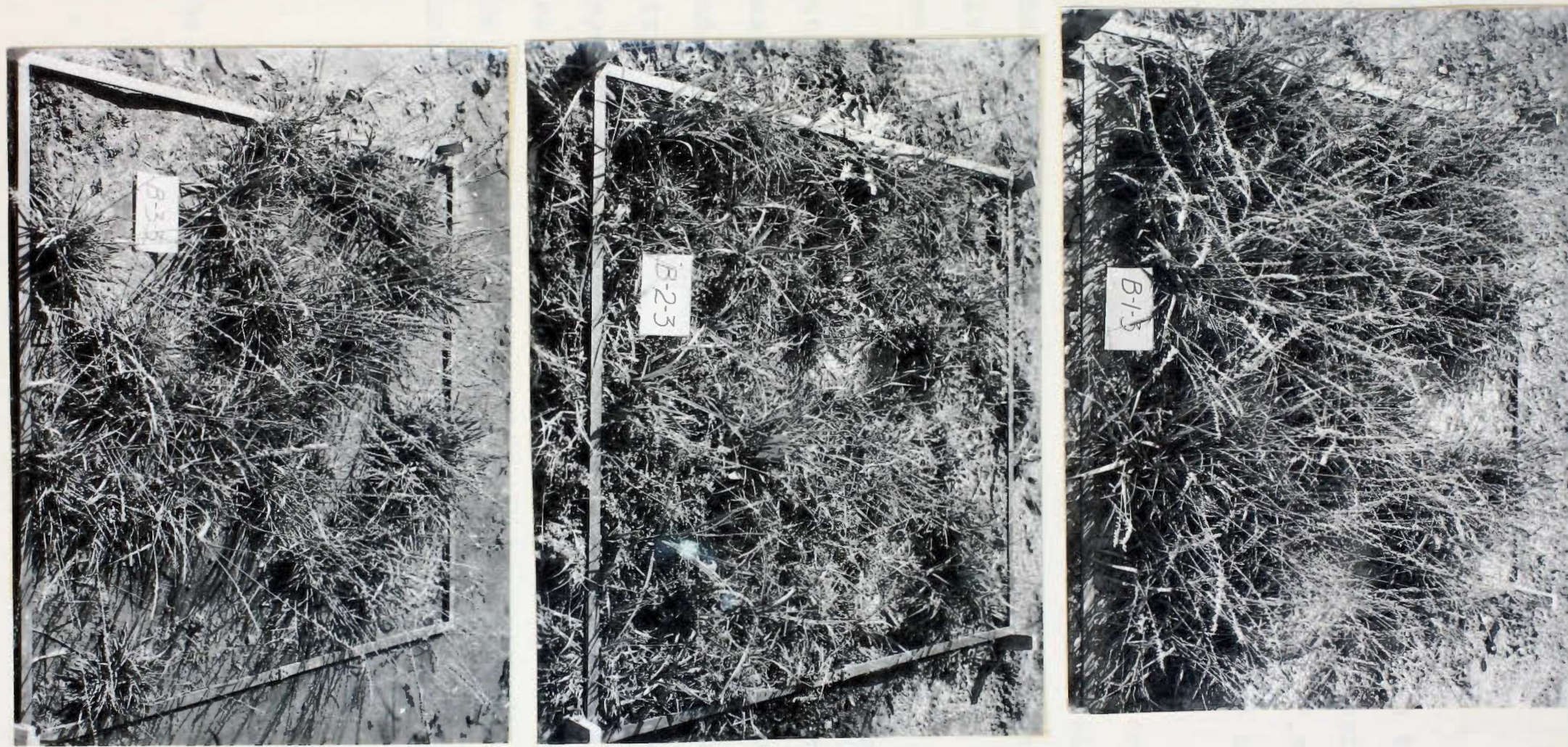

Fig. 10. Typical side-oats grama grass quadrats subjected to the various types of treatment. In B-1-3 (weeded but not clipped) the forage is dense and the flower stalks are long and heavy. In B-2-3 (not weeded but clipped) the cover is sparse and weedy and the flower stalks are very short. In B-3-3 (weeded and clipped) the leaves are short and the flower stalks are not as long as those in B-1-3. 
53 tillers per plant but only 25.8 survived to the end of the rroving season. The veeded anc clinned series lost nearly tive saine per cent of tillers, an averane of 92.7 per cent weing produced, but only 54.9 per cent survivine the season (Tables III and IV).

l'here was little äifference in tie busal cover between the weeded but not clipned and tine weedud and clipped series. L'he cover averafed $\varepsilon .39$ per cent and $\delta .19$ per cent, respectively. The basal cover on tie clipped but not weeded series avera eà orily 2.76 per cent (Fisure ll).

The response of the root systeils in the various quadrats vas siuilar to tiat of the other tvo species, but it was not as pronounced. Whe root sjsten of the unclipped anci weeded series penetratea tie soil to a depth of seventysix inches and had a spread of trienty-four inches. Tile deptin of the root system of the clipred but not veedea series was orly sixty incries and the spread was twelve inches. The weeded and clipred series hao a root systen seventj-tvo inches lon witi a spread of ei chteen inches.

\section{I S C USS I O l.}

The following observations were made from a study of the experi..ental áta. 
TrELT IV. The root and top $:$ rowth made by side-oats Jrama grass during the sumler of 1939. (E-I) weeded but not clipped, $(B-2)$ not weeded but clipped, and $(B-3)$ weeded and clippea.

\begin{tabular}{|c|c|c|c|c|c|c|}
\hline & \multicolumn{2}{|c|}{ I'illers } & \multirow{2}{*}{$\begin{array}{c}\text { Average } \\
\text { vield } \\
\text { (gis. })\end{array}$} & \multirow{2}{*}{$\begin{array}{l}\text { hverage } \\
\text { basal } \\
\text { cover }\end{array}$} & \multicolumn{2}{|c|}{ Root system } \\
\hline & Produced & $\begin{array}{l}\text { Number } \\
\text { survived }\end{array}$ & & & Lengtin & Spread \\
\hline$B-1$ & 143.1 & 143.1 & 159.1 & 5.39 & $6^{\prime} 4^{\prime \prime}$ & $24^{\prime \prime}$ \\
\hline$B-2$ & 53.0 & 25.8 & 82.3 & 2.76 & $5^{\prime} 0^{\prime \prime}$ & $12^{\prime \prime}$ \\
\hline$B-3$ & 92.7 & 54.9 & 111.0 & 8.19 & $6 \cdot 0 "$ & $10 n$ \\
\hline
\end{tabular}




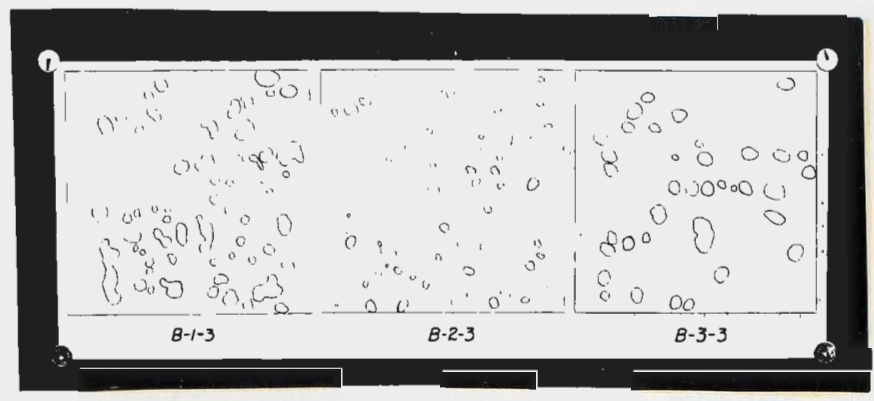

FiE. 11. 'Trpical sicie-oats srana quadrats. $(B-1-3)$ weeded but not clipperi, $(B-2-3)$ not veeded but clipped, and (5-3-3) veeded anc clipped. 


\section{TILIJR GROFTII}

The tiller srowtil of tie blue srama srass aid the side-oats zrama srass did not cive the same response to cliping (2). The createst rumber of tillers in the blue graila vas produced in the veeced and clipped series and the second larest number in those weeded but not clipped. I'he side-oats crawa was opposite in tiller growtin, the greatest number oI tillers being produced ou the weeded but not clipped series and the next larsest on those weeded and clipped (rables II and III). Lowever, in the weeded and clipped quadrats only slightly over half of the tillers survived the season, while all tillers in the weeded but not clipped quadrats were alive at tine end of the season. This difrerence was probably oue to the viriation in labit or grovth, the tillers of the blue srama beins fine and siort while those of the side-oats crama were heavy and long. rhe clipred but not weeced quadrats produced tine fewest tillars of my of tire quarats and a larje nu.ne- of these dic not survive the season. 'llhe severe competition for liwht and soil solutes, prosuced bu the fast frowing ruderals, retarded tine nornal tiller growti of these wasses to the extent that they vere bedly weakened. 


\section{YIELD}

The weeded but unclipped series of both blue grama and side-oats grama grasses produced the heaviest yield of forage. The reduction of the number of live tillers in the clipped and weeded series was probably a factor that helped to keep the yield from these quadrats low. The spread between the two probably would have been greater had the last clipping not been delayed to permit seed production. Two or three cuttings a year would probably increase the yield on all the species (6).

\section{GROUND COVER}

The mat-forming buffalo grass was greatly damaged by clipping and weed competition. There were no stolons more than four inches long produced and where these had taken root there were no stolons sent out beyond the new plants. It may be said that the ground cover at the end of the season was the same as it was when the seedling had become established. The fact that buffalo grass is a very low-growing plant allowed the weeds to shade it more quickly than the other species, thus hindering its growth.

In Series 3 the ground cover was greatly increased by the clipping process which caused the runners to lie close to the ground where the nodes could readily take root. The 
leaf blades were short and numerous, thus preventing an excessive reduction in leaf surface b.. cliphing. The riners vere very prolific, building up a mat which corpletely covered the cround. ieries 1 dia not produce as inch grounc cover because the stolons rer above the forage an did not take root as often as when they were next to the round. auch of its erowtis resulted in forage proauction, instead of runners. The bisal cover of the raias seemed to be reatest in tie unclipved quadrats. The blue rrana had 2 ; nore sround cover on the unclipyed quadrats than on tie clinped, and the siche-oats "rana had only $0.20,6$ wore sround cover. Cliping, as has beer siown above, killea many of the tillers, so the actual sround cover on tie clipped quadrats was probably not as oreut as snom by the panto raul records. .eed colpetition anc clipring reauced tive basal cover of blue grama to one-half that of tire weeded but rnclipped series; it reduced the side-oats grama to about oile-fourth that of the corresponding series.

\section{ROOT GIONTI}

The greatest reduction in root srorth accompanied the greatest reduction in top ronth in buffalo erass. In esch species the weed conpetition and clipwing sreatly recuced the root systeri. The side-oats erana was the least affected of all (1l). Its root system was reduced the least of any, 
beine only about twelve inches less tian tine weeded but not clinped series. The roots of blue grana in weries $A-2$ were heavier anō more nunerous but no lon er than those of buffalo rass in the correspondine series (Fig. 7). Clinpins alone recuced the root syztems of all the species but not to a very reat extent, the lensth being reduced from four to six incies and the spread from six to eisht inches. A recuction of this anount probably would not be very detrimental to the mrasses in becomine established.

$$
\text { A P P I I C } A \text { T I O I: }
$$

T'is experiment indicates that weeds siroula be ispt uncer control as nearly as nossiblo on revegetation areas. On areas large enouen to naire pullin: or hoeing weeds inpractical, mowing would be a cood metiod of cortrolling, tire weeas, if tire cover is set hisin enough to cut above the grasses.

Iight grazing on areas vitin a jood stard nisht prove helptul, providine climatic conditions were favorable, but in very dro seasons no srazi:1; should be practiced.

on areas vhere a tilin stand of native grasses already exists, it would be advisable to keep the weeds under control and protect it fron all but very light srazins. This method vill bring about conditions favorable to the reestablishment of the native grasses. 


\section{$S$ U II I R P Y}

1. Clippin and weed conpetition were very detrinental to all the grasses used.

2. Sliuping aided t'le spread of buffalo erass.

3. Wile yield was tne reatest on the nclinved quadrats.

4. Clining killed nearly half the tillers in the blue Grana and sioje-oats irana.

5. The root systens of all grasses useà were reảuced somewiat by clipping.

6. The root systeins were sreatly recuced by clipping plus week coipetition. 
1. Lisvell, narold $\mathrm{H}$. and eaver, J. L'. Effect of frequent clipping on the development of roots and tops of grasses in prairie sod. [Lancaster, Pa], 1933. 2lp. (Seprinted froin L'cology, vol. XIV, no. 4, actober 19331 . ping".

Yield of tops and roots in relation to clip-

2. Marrison, U..... and todson, C.". Lesno se of certain perennial grasses to cuttin treatrents. [iashington, D. C., Governinent printing office], 1939. 12p. (Reprinted from Journal of tis Ainerican Society of rgrono-1y, vol. 31, no. 5, iay 1939).

Clipping experi.uents with perennial srasses.

3. Leukel, H. A., Camp, J. P., and Coleman, J. Fi. sffect of frequent cutting and nitrate fertilization on the growtin behavior and relative composition of pasture grasses. [Gainsville], 1939. 47p. IUniversity of Horida, Hericultural experinent station bulletin no. 269, July 1934).

Yield and composition under clipping and fertilizing treatment. 
4. Richardson, A. E. V., Trunble, I. C., and Shapter, I. E. The influence of crowth stase and frequency of cutting on the yield and composition of a perennial Grass-phalaris tuberosa. Helborne, Hustralia, Government printine office, 1932. 35p.

The effect of the rovth stace and clipning on the vield.

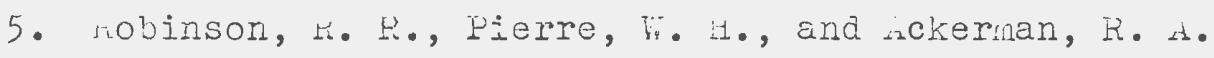
A comparison of grazine and clipping for deteruining the response of permanent pastures to fertilization. [tiashington], 1937. 10p. (Reprinted from Journal of the American Society of féronomy, vol. 29, no. 5, liay 1937). ization.

Discusses the response of pastures to fertil-

6. Hoberts, $R$. Allun and Hunt, $1 . V$. The effect of shoot cuttine on the srowtil of root and shoot of perennial rye-grass (Lolium perenne) and of timothy (phleum pratense). [Cardirf, iales, University of rales press], 1936. 16p. (keprirted from The Welsh Journal of Agriculture, vol. XII, 1936). shoots. hiesponse of the root syste:l to cutting of 
7. Lobertson, Joseph H. Iffect of frequent climing on the development of certain grass seedings. [Lancaster, ra.], 22p. (neprinted from Plant Physiology, vol. 8, p. 425-447). Iffects of clipping on root anà top growth.

ن. Jampson, artlur $\%$. Rane and pasture management. Let. Yoris and London, John :iley ano sons, [ $\left.{ }^{\mathrm{C}} 1923\right] .421 \mathrm{p}$. Contains chapter on reveretation by imported and cultivated species.

9. iesver, J.L. Undereround plait developient in its relation to mrazin.. [Lancaster, Pa.], 1930. 14p. (reprinted froril Jcolosv, vol. II, no. 3, July 1930).

Iffects of rrazirs on root developinent.

10. and ilbertson, F. $\because$. . Detericration of midwestern ran es. [Lancaster, Pa.], 1940. 20p. (keprinted from Icology, vol. 2l, no. 2, April $1940)$.

Discusses the effect of arount on pastures and ranges.

11. and Ilaucen, $V$. iI. Effect of frequent clipping on plant production in prairie and pasture. 
[Notre Dame, Indiana], 1939. 18p. (Reprinted from The American Midland Naturalist, vol. 2l, no. 2, March 1939).

Ixperiment carried out under field conditions. 